\title{
Refraction of Rock Culture Through a Prism of Japanese National Traditions: The Works of the Onmyo-Za (J-Rock) Band
}

\author{
Elvira A. Danilova ${ }^{a}$ \\ and Natalia A. Elovskaya ${ }^{\text {b* }}$ \\ ${ }^{a}$ Krasnoyarsk State Medical University \\ 1 Partizana Zheleznyaka, Krasnoyarsk, 660022, Russia \\ ${ }^{b}$ Krasnoyarsk State Institute of Arts \\ 22 Lenin Str., Krasnoyarsk, 660049, Russia
}

Received 15.01.2016, received in revised form 24.07.2017, accepted 04.08.2017

The article is devoted to the consideration of the peculiarities of the American-European rock culture in the key of the musical, literary and general cultural traditions of Japan. The main purpose is to reveal the features of the Japanese national art, which are piercing the work of the Japanese rock band Onmyo-Za. The fundamental methods of the research were the method of historical and theoretical musicology, as well as the linguistic and content analysis. Based on the material of independent music compositions and compositions that make up the albums, the article considers specific examples of cultural refraction that have arisen in connection with the typical features of the Japanese mentality: borrowing and modifying foreign features in accordance with their traditions and philosophy. The Onmyo-Za band is the confirmation of the principle of synthesis of traditional and American-European principles taken as a basis for this work. The compositions are distinguished by the organic nature of the fusion of the Japanese national culture and western rock music. Traditionally, the Japanese manifested itself both at the contensive, figurative-semantic level and at the musical level. The study showed that the style of the Onmyo-Za band is an example of rock music with an organic embodiment of the distinctive features of Japanese traditions inscribed in the world context of rock culture.

Keywords: J-Rock, Japanese, Heian, traditional music, poetry, Japanese poetry, rock, images, musical instruments, Gagaku.

DOI: 10.17516/1997-1370-0123.

Research area: culturology, art criticism.

Rock music is a very significant component of a large-scale phenomenon that arose in the second half of the $20^{\text {th }}$ century - rock culture that represented a variety of social, political, spiritual, aesthetic and artistic aspects.
Due to the fact that rock was formed and developed from the very beginning in Western culture, European-American rock music has been thoroughly studied in the diachronic and synchronic aspects. In the Far East this direction

(C) Siberian Federal University. All rights reserved

* Corresponding author E-mail address: eri_e-ri@mail.ru; elovska@mail.ru 
appeared by borrowing much later and at the present time has not yet been comprehensively considered for this reason, and also due to the apparent Western-centricity of the majority of music studies. Japanese rock music (J-rock) remaining a white spot on the musicology map is a very curious material from the point of view of the manifestation of not only the features of modern Western culture, but also the features of the traditional culture of Japan.

Such musical directions as jazz, alternative rock and metal have brought significant influence on J-Rock (Jap. ジェイロック). The experiments with sound and significant mixing of different directions can be distinguished as one of the features of J-Rock. The influence of such heavy directions as metal and hardcore is manifested in the use of more "heavily" tuned guitars in a flat pitch Es by most bands than it is accepted for other national rock stages.

The Japanese people have always been famous for their ability to perceive the achievements of other peoples and, by letting the alien through the prism of the national, to create something qualitatively new. This trend can be observed not only in the field of life, technology, but also in the sphere of culture, literature, music and religion.

The combination of purely Japanese and Western rock music in the works of the OnmyoZa band briefly considered in this article can be written into the concept of ethno-rock, however, the traditional imposition of a borrowed tradition on a deeply national one is not a tribute to fashion, but is a need of the Japanese mentality itself. J-Rock as something little studied is of interest to musicologists, and this synthesis of the West and the East only intensifies the interest in this direction.

In the life of the ancient Japanese society, like, perhaps, any other, the value of a song accompanying work, ritual and leisure was significant. The most important role in agricultural ritualism and accompanying songs was played by the ancient folk belief 言霊の信仰 (kotodama no shinko - "faith in a word's soul", i.e. in its magical power).

The first written monuments of Japan, which arose in the Nara era (710-794), are the Kojiki Records of ancient matters (712), the historical chronicle Nihongi - The chronicles of Japan (720), historical-geographical and ethno-topographic Fudoki records - The records of customs and land (713-733) and the first literary monument of written poetry Man'yoshu - Collection of Ten Thousand Leaves (second half of the $8^{\text {th }}$ century).

The songs Kojiki and Nihongi, which are defined as examples of the primitive ancient Japanese poetry, also deserve attention. The original name of these songs is 物語の歌 (monogatari no uta - "songs in narrations"). Among the monogatari no uta interspersed with a prosaic narrative fabric and associated with it, there are love, feasting and military songs, as well as the songs related to hunting, with ritual, weeping. They are songs of different sizes, unstable meter, unstable stanza. In the texts of the chronicles one can meet both 片歌 (katauta, i.e. “tercets”), 短歌 (tanka, i.e. “pentastiches”) or旋 頭歌 (sedoka, i.e. “sextains”), and 長歌 or 長唄 (cho:ka or nagauta, i.e. "long songs").

The Kojiki songs use techniques and artistic means of folk poetry: parallelisms, repetitions, rhythmic choruses, epithets, comparisons, less often one can notice a hyperbole and an allegory; assonances, alliterations are often used. It is well known that in Japanese poetry there is no rhyme as a poetic technique, but due to the syllabic character of versification and the properties of the Japanese language in the songs, random rhymes, both internal and external, can occur.

In the poems and songs of the Man'yoshu anthology various aspects of the life of Japan of that period are reflected: nature, way of 
life, customs, traditions and rituals, historical events. The wide chronological framework of the Man'yushu makes it possible to trace the literary processes that led to the creation of a certain artistic system that contributed to the establishment of canonical poetics.

By the $8^{\text {th }}$ century lyrical themes of each season, specific images, superstitious beliefs and special "seasonal aesthetics" were fully defined and in the subsequent history of Japanese landscape lyrics began to play an important role. The main superstitious beliefs and images for the spring were a light mist, a green willow, a nightingale, plum blossoms, cherries; for the summer - a cuckoo, flowers of unohana, oranges, cicadas; for the autumn - Hagi flowers, scarlet leaves of maple, a moaning deer, cries of wild geese, croaking of frogs, a rice field, dew, wind; for the winter snow; and for the late winter, just like the early spring, - plum blossoms. Most "seasonal images" subsequently become the canonical images of the annual cycle in Japanese art.

Having taken the leading place at the first stage of the history of Japanese literature, lyrical poetry determined the character and further development of the literary process in many ways. Just like in the history of music, the Heian period is considered as the blossom of court literature, both prose and poetry. Since the field of interest of the J-Rock band analyzed by us is largely based on the achievements of the Heian period, its spirit, we allowed ourselves to dwell upon the development of literature and music in this historical period.

The music of Gagaku is the most significant in the future cultural development of Japan. The basis of the Gagaku was the ritual music of China and Korea, but with a slightly different content: it is no longer a ritual act in honour of the Gods, Confucius or the ruler, but the court-ceremonial music performed during receptions and feasts in the imperial houses.
The instruments of the Gagaku consist of wind instruments (sho - a mouth organ, hichiriki - a double-reed flute, ryuteki - a transverse flute with 7 holes, kagurabue - a flute and komabue - a flute), fretted instruments (so or gakuso - a 13-string zither, a predecessor of koto; wagon or Yamatogoto - a smaller-sized zither with 6 strings; biwa or gakubiwa - a lute with 4 strings) and percussion instruments (5 drums of different size and configuration: Da-daiko, taiko, shoko, kakko and sannotsuzumi). Wind hichiriki, ryuteki, kagurabue, komabue lead the main melodic line, the performers on the kakko and sannotsuzumi drums take on the functions of the conductor.

One of the most important directions of the traditional music of Japan is the music of the Noh theatre called nogaku, which consists of three forms: solo singing of actors, singing of the male choir and the music of the instrumental ensemble.

The melody of solo and choral singing yokyoku - can be compared with the recitative singing of the Western European opera, but it is more melismatic. The meteoritmic organization of yokyoku is quite complex. Yokyoku performed outside the connection with the metric structure are called hyoosivadzu, and yokyoku with a clear metrorhythmic organization - hyooshiai. The performance of the yokyoku is detached and muffled creating a feeling of unreality of what is happening.

Briefly describing the further musical formation, we should note that in the Kamakura period, when Buddhist ideology was rethought for the service of samurai, music was freed from magnificent refinement and became simpler in form and more democratic in content. At the beginning of the $17^{\text {th }}$ century the internecine wars were stopped by a new shogun, Tokugawa Ieyasu, who completed the unification of Japan. With the creation of a strong centralized power and the establishment of peace, a period of rapid 
flourishing of secular culture and, at the same time, active democratization emerges. Second half of the $19^{\text {th }}$ century is marked by the penetration of elements of European and then American music into Japan. Already in the middle of the $20^{\text {th }}$ century in Japan, various genres of popular musical culture, including popular music and rock music, were fully and finally distributed.

The historic moment in the formation of many directions of Japanese rock music was the performance of the American band Kiss in Tokyo in 1977. This rock band was one of the most famous bands of the 1970's-1980's working at the junction of glam rock and metal. An important role in their popularity among the Japanese youth was played by spectacular make-up, a shocking image and a bright stage show.

J-Rock can be divided into the following genres:

1. Visual kei translated as a "visual style" derived from Japanese rock, glam metal and punk rock with an emphasis on the performers' appearance.

2. J-metal includes Japanese metal bands. The most common are such genres as neoclassical power metal. Unlike bands of more modern metal genres (nu-metal, modern-metal, alternative metal) sticking for the most part of visual kei, the neoclassical power metal bands have a more Europeanized sound. The bands Concerto Moon and Galneryus were the most famous in these two genres.

3. J-Ska is a style of Japanese music that is both a separate style and sub-species of the J-punk genre. This style includes both the inherent Jamaican motifs and the addition of J-punk/J-rock/Jazz motifs. The leading bands are Muramasaz and a completely female band called OreSkaBand.

4. The J-punk movement originated in the 1970 's in connection with the popularity of the British band The Stranglers in Japan. It often declares social and political themes.

Since J-Rock is an important part of Japanese culture and along with J-pop anime is used in the soundtracks, this musical genre has become widespread among fans of anime, as well as of the whole of Japanese culture around the world.

The bands working in the genre of J-rock are mostly oriented to the local audience, their repertoire is dominated by songs in Japanese; there are not that many bands performing songs in English.

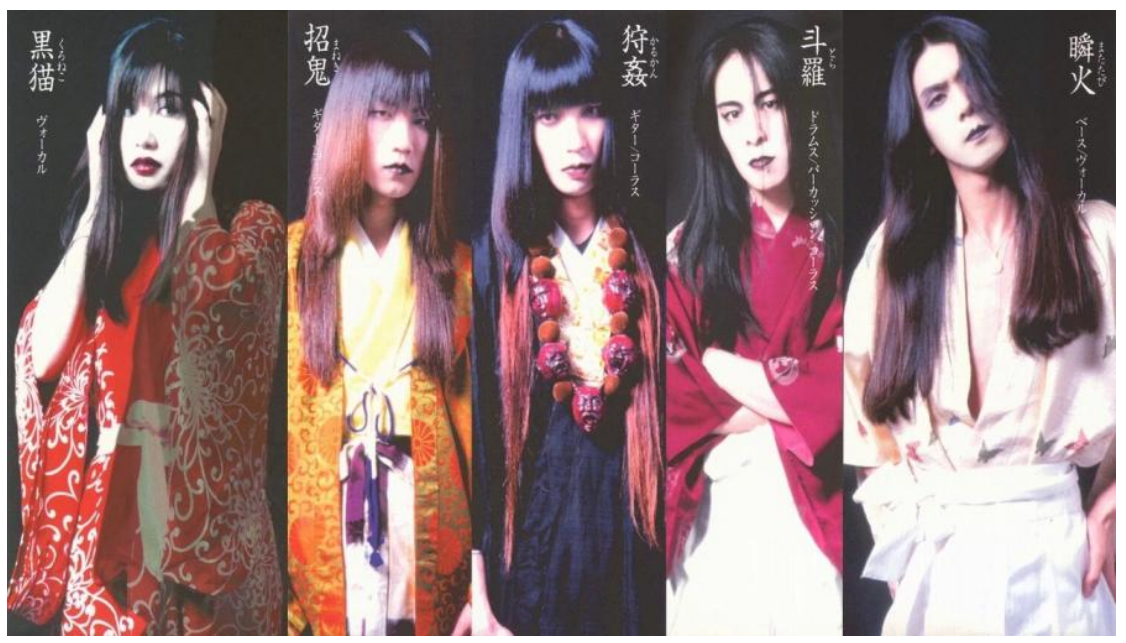

Fig. 1. Members of the Onmyo-Za band (from left to right: Kuroneko, Maneki, Karukan, Tora, Matatabi) 
Let us dwell upon the works of the OmnyoZa band (Fig. 1) that fits in the genres of ethnorock in the synthesis with hard-rock. Omnyo-Za was formed in Osaka in 1999, first as a quartet composed of Matatabi (vocals, bass guitar), Kuroneko (vocals), Maneki (guitar) and Karukan (guitar).

The first performance of the band took place on June 20 in the Osaka Brandnew. At first the band played without a drummer, but soon this place was taken by Tora (who left the band in 2009). At the moment, the band also has support members - Tomotaka Ishikawa on drums and percussion, as well as keyboardist Abe Masahiro. Initially, Omnyo-Za was an indie band, independent and self-produced, but thanks to the bright performances, high level of performance and tireless enthusiasm of the band, in 2001 they a professional agency became interested in them and Onmyo-Za became a major, commercial music band by signing a contract with The King Records label. In 2002, the band toured all over Japan, and in the autumn of 2005 gave three concerts abroad: in Belgium, France and
Germany. Despite the fact that the band was formed more than 10 years ago, Onmyo-Za still continues its activities.

The very name of the band reflects the essence of its work and the direction that the band members adhere to. Onmyo-Za - 陰陽座 is an old reading of hieroglyphs meaning the fusion of Yin and Yang. The combination of the first two characters - 陰陽 (onmyou) - also gives the name a certain meaning. In the Heian period, witches called onmyouji (陰陽師), spiritual advisers, soothsayers and spellcasters of evil spirits lived in Japan.

At the moment, Onmyo-Za is one of the most unusual bands in Japan, a unique phenomenon of modern Japanese music. Its music is heavy metal of the Western origin mixed with traditional Japanese melodies, and its texts are a description of scenes from ancient Japanese mythology in kogo, "the ancient language". In the music of Onmyo-Za there are epic thrillers, ballads and dance melodies with a touch of funky style.

In the lyrics of their songs, the Onmyo$\mathrm{Za}$ band uses expressions that have long been

Table. Ballad "Tsukihime"

\begin{tabular}{|c|c|c|}
\hline $\begin{array}{l}\text { 嗚呼 闇に凍える私は月 } \\
\text { 幽かな光を 肌にに 纏い }\end{array}$ & $\begin{array}{l}\text { Aa yami ni kogoeru watashi wa } \\
\text { tsuki } \\
\text { Kasuka na hikari wo hada ni matoi }\end{array}$ & $\begin{array}{l}\text { Ah, I'm frozen in the darkness of the } \\
\text { Moon. } \\
\text { A faint glow envelops my skin. }\end{array}$ \\
\hline $\begin{array}{l}\text { 空を満たす 水の様に } \\
\text { この身を溶かす 腕を待ち } \\
\text { 侘びる }\end{array}$ & $\begin{array}{l}\text { Utsuho wo mitasu mizu no you ni } \\
\text { Kono mi wo tokasu kaina wo } \\
\text { machiwabiru }\end{array}$ & $\begin{array}{l}\text { Like water filling a void, } \\
\text { I was waiting for the hands to melt my } \\
\text { body. }\end{array}$ \\
\hline $\begin{array}{l}\text { 徒恋 それとも 運命の糸 } \\
\text { 叶わぬ 遥かな夢か幻 }\end{array}$ & $\begin{array}{l}\text { Ada koi soretomo sadame no ito } \\
\text { Kanawanu haruka na yume ka } \\
\text { maboroshi }\end{array}$ & $\begin{array}{l}\text { Vain love? Or is it a thread of destiny? } \\
\text { Unfulfilled, distant dreams or visions. }\end{array}$ \\
\hline $\begin{array}{l}\text { 消せぬ想いは } \\
\text { 密んで嚨の雲に }\end{array}$ & $\begin{array}{l}\text { Kesenuomoi wa oboro no kumo ni } \\
\text { Hisonde nageku namida wa chi wo } \\
\text { nurasu }\end{array}$ & $\begin{array}{l}\text { An indestructible idea hidden in shaky } \\
\text { clouds } \\
\text { Irrigates the ground with bitter tears. }\end{array}$ \\
\hline $\begin{array}{l}\text { 私の光が消えぬ間に } \\
\text { どうか呪縛を断ち切って }\end{array}$ & $\begin{array}{l}\text { Watashi no hikari ga kienu ma ni } \\
\text { Douka noroki wo tachikitte }\end{array}$ & $\begin{array}{l}\text { While my light is not extinguished, } \\
\text { Please, destroy the curse. }\end{array}$ \\
\hline $\begin{array}{l}\text { 風はいつしか雲を散らし } \\
\text { 彼方の空に光は満ちる... }\end{array}$ & $\begin{array}{l}\text { Kaze wa itsushika kumo wo chirashi } \\
\text { Anata no sora ni hikaru wa } \\
\text { michiru... }\end{array}$ & $\begin{array}{l}\text { The wind will scatter clouds in the } \\
\text { blink of an eye, } \\
\text { And your sky will be filled with } \\
\text { radiance again... }\end{array}$ \\
\hline
\end{tabular}


out of use in modern Japan. And although this makes the texts rather vague and sometimes incomprehensible, the band manages to recreate the spirit of classical literature, the poetry of ancient Japan. Usually the composition OnmyoZa describes a mythological being, most often not directly itself, but through a set of properties associated with it. For example, in the ballad “Tsukihime” (月姫) (Tabl.) there is a content of one of the most famous Japanese fairy tales “Princess Kaguya” (かぐや姫).

If we refer to the translation of the song ${ }^{1}$, it should be noted that the text does not mention the name of the princess, but due to the popularity of this story in the Japanese culture, the phrases that were used are enough to make the listener understand what is being said.

The tale tells of the life of a girl named Kaguya-hime (Fig. 2) who was found as a baby in a stem of a growing bamboo and possessed amazing beauty. Rumours of her beauty spread far away, and even the emperor of Japan fell in love with her and proposed to her. Kaguya refused to marry him, like others, saying that she was from the Moon Kingdom, and she would soon be taken back.

When this happened, the girl was very saddened that she had to leave dear people. She sent the emperor a farewell letter and an elixir of life as a gift.

Having received the letter from the princess, the emperor ordered to carry his reply to the mountain nearest to heaven and burn it there hoping that Kaguya would receive a message. Along with the letter, the elixir of immortality was burned, since the emperor did not want to live forever without Kaguya. The legend says that the name of Mount Fuji derives from the word “immortality" (不死 fushi or fuji). It is also believed that the smoke from the fire, in which the emperor's message was burned, is still rising above the mountain.

In addition to the most veiled plot, there is also another Japanese symbol - a thread of destiny. The so-called "red thread of destiny" (運命の赤い糸) is a popular belief in Japan,

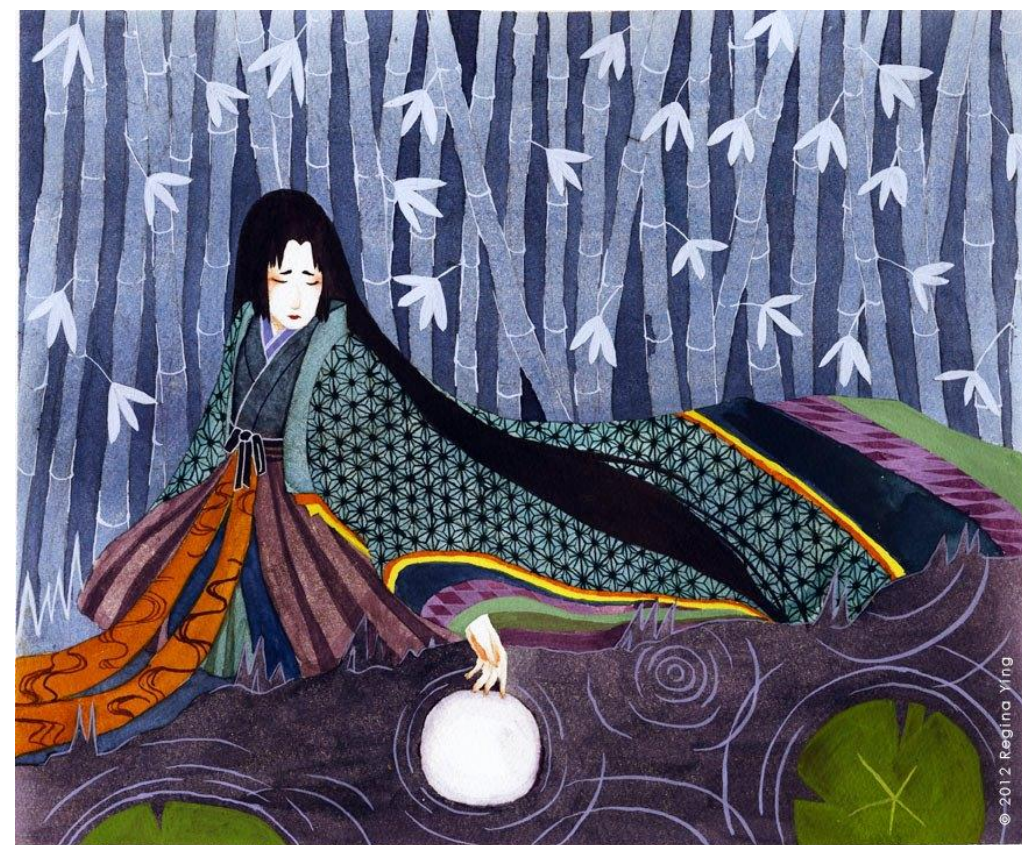

Fig. 2. Kaguya-hime 
according to which an invisible red thread appears on the little fingers of a man and a woman linked together. For this thread there are no obstacles to the circumstances, time or distance, it is reduced until the two meet each other.

The image of the Moon that is constantly encountered in Japanese folk and classical poetry is no less typical. It is well known that the Moon is a kind of a symbol for the Japanese. It is no accident that they have a tradition of admiring the full moon.

Let us turn to other musical compositions of the band. In the culture of rock, the issue of defining a rock album as a special genre can be singled out. The album assumes a special type of artistic communication - listening to a disc. Unlike classical music, where the disc is only a way of distribution of music, the album recorded on a disc is the main form of existence for rock music. Thus, rock albums often have a combination of signs of chamber and concert music making. The work of a sound engineer is especially important. $\mathrm{He}$ creates a voluminous stage, decorations, accompanies a performance making the listener completely immersed in music. The success of the album, the expressiveness and variety of sounding of instruments and vocals, the balance of these plans, the natural perception of music largely depend on him. A rock album is a fixation of a single, and therefore an ideal musical concept; all the improvisation that occurs during the recording of a disc becomes part of a hardcoded original. The genre of a rock album allows using all variety of musical genres and means subordinating them to its specificity. In a new context, a symphony orchestra, choir, traditional instruments acquire the meaning of a part of the whole.

Interestingly, the use of the genre of the rock album corresponds simultaneously to the peculiarities of both folk and Japanese musical cultures: since ancient times, cycles and suites, both instrumental and vocal, have been common in the traditional music of Japan.

Kumikyoku Kishi-bojin (a suite "Kishimojin") - is an album from the repertoire of the Japanese rock band Onmyo-Za consisting of 12 tracks. According to the band members, the idea to write a musical composition reflecting the plot of the legend about Kishimojin ${ }^{2}$, came up at the time of the formation of the band, and the interest remained throughout twelve years (the band was formed in 1999, and the suite Kishimojin was released in 2011). For the collection of songs to be perceived as a suite, the musicians, as they said, have recorded it as "one huge song". The total duration of sounding exceeds one hour and the tuning of guitars was in a lowered tone (a pitch $\mathrm{E} b$ ). In the process of recording the album, Dobasi Makoto was a drummer and Abe Masahiro played keyboards. Explaining the reason for the choice of the plot, the leader of the band Matatabi said that he wanted to change human society with the help of music, just as the character of the main heroine of the songs, Kishimojin, was aimed at the true path in the narrative.

The definition of "kumikyoku" given by the authors means "a suite". It can be compared with the concept of traditional Japanese music "kumiuta" - both are suites ("kumi" - "a gathering, a group", "uta" - "a song"). However, if the traditional suite-kumiuta usually does not have a plot, then the kumikyoku has a clear storyline evolving throughout all parts, which can be observed in this work.

Moreover, proceeding from the narrative fullness of the songs, it is possible to distinguish 3 figurative groups: a legendary-demonic group, a group of images of restless wandering souls and a group of Shinto spells to the deified forces of nature. An interesting feature of the suite is that another key element in it was the tonality of the D minor, which sounds almost in all compositions. 
Certain musical means are characteristic for each group of songs, including a tonality different from the basic one in compositions belonging to the group of prayer-pantheistic images.

It is also interesting that the first track of the Kishimojin suite - the instrumental introduction of Shuushuu - "Lament" (similar to the kabuki music) can be heard one more time later on - as an introduction to the last part of the kumikyoku. Thus, an architectonic arch is created that unites the whole cycle. Shuushuu is a kind of a prologue on behalf of the author-narrator, the beginning of the legend unfolding before our eyes. The first track prepares the listener for further events: later in No. 6, which has the same narrative tone as the introduction, similar melodic moves will sound.

Performing the role of the cycle's closing, the composition Kikoku ("Writhing of ghosts") generalizes, collects and concentrates the motifs and images that took place earlier in the cycle: wind, mountain peaks, quivering flowers, wayward souls, their anger, sorrow, blood tears, wanderings, demons, abandoned children's clothing as a symbol of a loss of a child. However, its tone is very personal, open and emotional, it is a desperate confession torn from the heart, and sometimes it even sounds like a cry, a complaint that gives this composition an even more subjective character.

To create it, the vocalist of the band Kuroneko sings with a half-open sound, a ternary meter of the song in her party sounds floatingly over the duple nature of the main meter for the rest of the band. Her speech does not obey the general metro-rhythm of the movement overcoming it, rushing forward, which emphasizes the openness, sincerity of experiences. Thus, on the one hand, the closing fixes everything that happened during the cycle, and on the other hand, thanks to the sounding different from the other songs, a new presentation of images opens in it. This allows us to conclude that this song is a real, true closing of the suite both in terms of the semantic and the musical drama. Before the last two chorus performances, the theme from the first composition, which smoothly flows into a technical guitar solo, is included again. The concluding chord of the closing is another final performance of the musical theme of the introduction - the narrator finished his song.

The songs of the suite-kumikyoku are built on the principle of contrast alternating of compositions of three different figurativesemantic groups forming a symmetrical concentric form that contributes to the integrity of the cycle, its cohesion (Fig. 3).

The musical means of the suite are also aimed at combining the compositions into a single whole. Each of the three marked story groups has a common means of expressiveness differing from others. Thus, in the first group that can be called a group of lament of "restless souls" (No.1 Lament, No.2 Wandering, No.4 Namasu, No.10 Path, No.12 Wailing of ghosts), both soloists of the band are involved - either singing a male-female duet or alternately (except for No.12, where the singer is the vocalist Kuroneko). Among other things, special techniques of the vocal phonation are characteristic for these songs. Also in all the median compositions of this group there is one

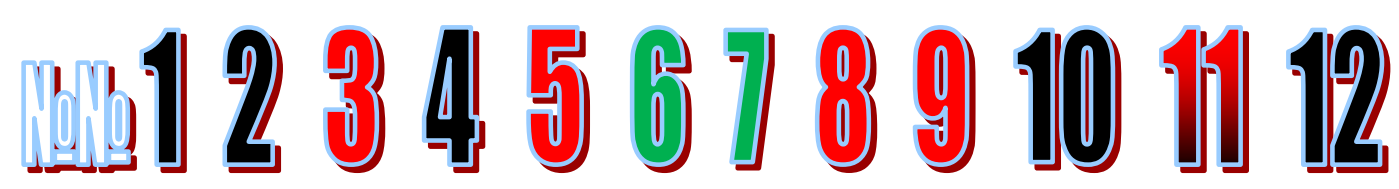

Fig. 3. Black colour - images of restless wandering souls. Red colour - legendary-demonic images. Green colour - images of pantheistic spells 
hard riff, except for the introduction (No.1) and the closing (No.12). In addition, the last songs are the only tracks that differ by the inclusion of the keyboard sound, which again emphasizes their role in building the arched drama of the suite.

The second group figuratively designated as a group of legendary-demonic images, includes No.3 Children's clothing, No.5 Song of the demonic creation, No.8 Kishimojin, No.9 End of soreness, No.11 Bloody tears. These songs are mostly performed only by the vocalist Kuroneko, except for No.9, where both singers sing alternately. A special feature of this group is the increased role of the instrumental principle, ostinatism; the role of percussion is great. A characteristic feature of this group is the inclusion of recitatives of the choir or male performers of the band who enter into a dialogue with the soloist, while the choir performs the role of entry (No.5) or conclusion (No.11). All this resembles the features of a theatre. But, in general, staginess is an important quality of compositions of this group. Also the tonal fallout No.11 is not accidental here - this composition is important in a dramatic and semantic plan, here we see the transformation of the demoness who has been eating children and now comes to repentance. In connection with all of the above, this composition was defined as bifunctional.

The group of prayer-pantheistic lyrics includes No.6 "Moonlight" and No.7 "A spell and a pomegranate tree" that are in the centre of the cycle and perform the role of a certain musical interlude. They are united by a common lyrical state of light sadness. Such a state of soul that can be noticed in these compositions is called mono no aware in Japan (物の哀れ "sad charm of things") - an aesthetic principle, in the understanding of which the emotional response of a person is similar to the feeling of enchantment by the sheer and implicit beauty of things and phenomena, while there is always a shade of reasonless sadness caused by an inner sense of illusory and frailty of everything in any such response. Here, there is domination of the vocal part over the instrumental one, more chamber instrumental composition and muffled percussions, there are no riffs, and both songs are close to melodious compositions, rather than the rock ones.

These songs are distinguished by not only their mood, but also tonally: if both groups of demonic and psychological images are almost completely in D minor, then these two compositions creating a fragile image of a Japanese nature, from which it is customary to ask for help, although also minor, but sound higher in g-moll - and, moreover, are often perceived tonally more vaguely, which increases fragility, tenderness and certain unreality.

Thus, the transparent figurative and dramatic development and unity of means of musical expressiveness of the whole cycle unites twelve songs of kumikyoku into one implementing it in the genre of a rock album that embodies the typical features of rock culture and, at the same time, the national characteristics of traditional Japanese music.

Drawing inspiration from traditional stories about the spirits and ghosts of kaidan and modern writers and mangacs, Onmyo-Za writes music that is sinister and beautiful, encouraging and frightening.

Another feature is manifested in the looks of the band members. Unlike most representatives of J-Rock who prefer western costumes, the Onmyo-Za musicians are dressed in traditional Heian costumes ( $7^{\text {th }}-8^{\text {th }}$ centuries) (Fig. 4$)$.

Onmyo-Za compositions are based on traditional Japanese poetry and music: images of nature, legendary-fantastic images (especially all kinds of demons) and fairy-tale stories. Musically, there is tonality of Japanese music (halftone pentatonism, tencho - combination of 


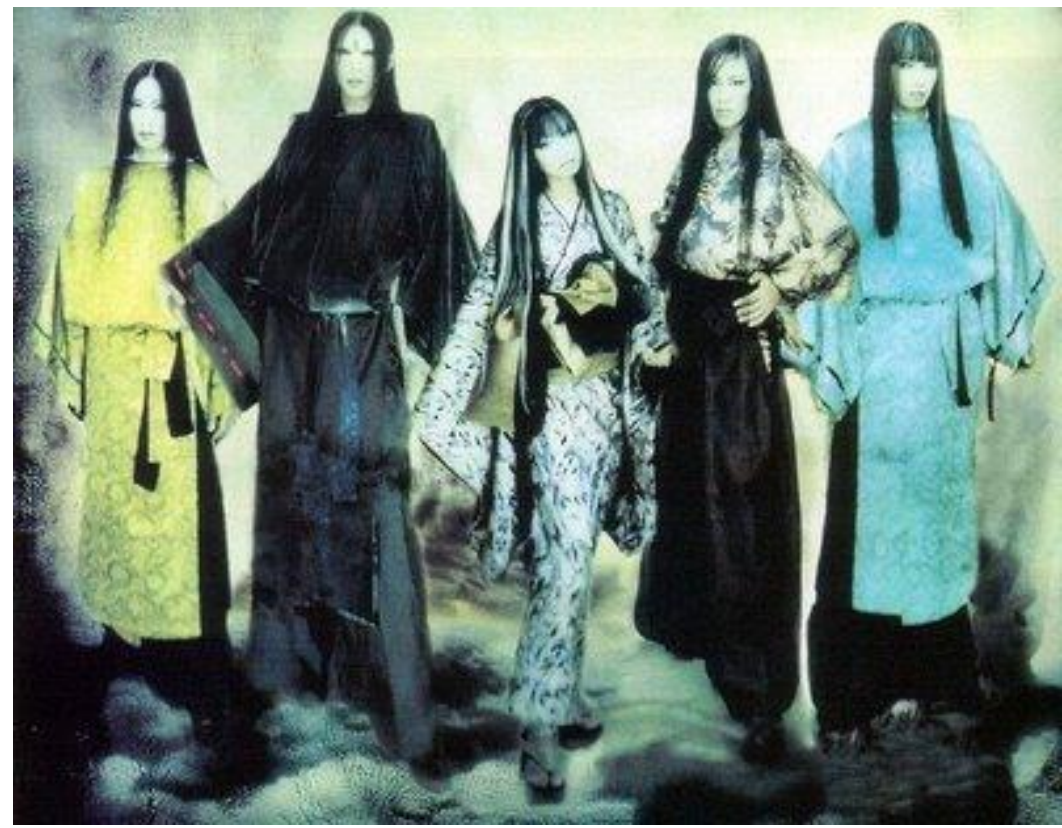

Fig. 4. Band members in traditional costumes

two trichords with the help of a common tone, the koto mode), genres (nagauta, kumiuta); the features of the Noh theatre (not only in music, but also in scenic acts) are especially pronounced in the work of Onmyo-Za. Here we can also include a timbre palette (imitation of the timbre of folk instruments and their use, especially flutes) and the timbre of a female voice (characteristic Japanese vibrato, speech intonations). At the same time, it is heavy rock with all its features (riff structure of compositions, virtuosic solo guitars, tension, energy, drive).

Thus, the works of the Onmyo-Za band are an organic synthesis of the characteristics of Western rock and Japanese musical and poetic traditions that have their origin from time immemorial, which creates a unique image of this band.

\footnotetext{
Interlinear translation into Russian by the author of the article E.A. Danilova.

2 The legend of Harity (Kishimojin) and Buddha Shakyamuni.

Initially, Hariti was a rakshasi - an ogre demon who had hundreds of children whom she cherished and loved. Their father was Panchika, one of the 28 natural spirits of the Yaksa-generals of the spirit of Vaishravana's wealth. To feed her children, Hariti kidnapped babies from other people and fed her children with their flesh. Gautama Buddha was asked for the help and rescue of the mother of the dead children. After listening to them, Gautama kidnapped Hariti's youngest son, Aiji, and hid him under his rice ball. Vainly she sought for him in all corners of the universe, and in the end she was forced to ask for help from Gautama. The Buddha pointed out her suffering because of the loss of one son out of a hundred and asked to imagine the suffering of mothers who lost their only child. She admitted that the sufferings of these mothers are hundreds of times greater and vowed to protect all the children.
}

\section{References}

Dubrovskaya, M.Yu. (2012). Muzykal'naya sintologiia i problemy izucheniia iaponskoj kul'tury [Musical shintology and questions of japanese culture research]. In Problemy muzykal'noj nauki [Questions of musicology], (2), 12-16.

Erengross B.A. (2001). Mirovaia hudozhestvennaia kul'tura [World art culture]. Moscow, Vysshaya shkola. $767 \mathrm{p}$.

Esipova, M. (2001). Muzyka Iaponii v istoricheskikh vzaimodejstviiakh [Japanese music in historical interactions]. In Muzykal'naya akademiya [Musical academy], (2), 156-165. 
Goreglyad, V.N. (1989) Nekotorye tendencii razvitiya yaponskoj kul'tury [Some tendencies of the Japanese culture development]. In Iaponiia: ideologiia, kul'tura, literatura [Japan: ideology, culture, literature], 4-9.

Iaponskaia literature [Japanese literature]. (1984). In Istoriia vsemirnoi literatury v 9 tomah [World literarure history in 9 volumes], Moscow, (2), 160-172.

Inoue Takako. (2003). The era of Visual kei [Visual kei no jidai]. Tokyo: Seikyūsha. 277 p.

Ivanova, O.F., Anashkina, E.V. (2015). Evfemizmy v iaponskom iazyke: rezul'taty issledovaniia nekotorykh tematicheskikh polej [Euphemisms in Japanese: a Study of Some Thematic Fields]. In Humanities and Social Sciences, (8) 9, 1864-1876.

Kul'tura [Culture] (2008). In Iaponiia ot A do Ia. Entsiklopediia (CD) [Japan from A to Z. Encyclopedia (CD)].

LyricWiki: Onmyo-za. Available at: http://lyrics.wikia.com/陰陽座_(Onmyouza) (accessed 17 June 2013).

Povest' o starike Taketori (Taketori-monogatari) [The Tale of the Bamboo Cutter (Taketorimonogatari)] (2003). In Starinnye iaponskie povesti [Old Japanese stories]. St. Petersburg, SeveroZapad Press, 7-57.

Tatarskaya, D.A. (2015). Iaponskaia kul'tura skvoz' prizmu arkhaiki (na primere kontsepta «dusha») [Japanese culture in the light of archaic: a case study of the concept of 'soul' ('tama')]. In Voprosy kulturologii [The culturology issues], (9), 32-37.

The Official Onmyo-Za web-site. Available at: http://www.onmyo-za.net/eng/index.html (accessed 17 June 2013).

"There has to be a "red string of fate..." ["Akai ito» tte aru no da na...»]. Available at: http:// www.geocities.co.jp/Milkyway-Lynx/5368/ (accessed 5 September 2013).

U Gen-Ir. (2012). Traditsionnaia musyka Dal'nego Vostoka (Kitai, Koreia, Iaponiia): Istorikoteoreticheskii analiz [Traditional music of Far East (China, Korea, Japan): Historical and theoretical analysis]. St. Petersburg. 544 p.

Wikipedia: J-rock. Available at: http://ru.wikipedia.org/wiki/J-Rock (accessed 6 May 2013).

Wikipedia: Onmyo-Za. Available at: http://ja.wikipedia.org/wiki/陰陽座 (accessed 6 May 2013). 


\title{
Преломление рок-культуры
}

\section{сквозь призму японских национальных традиций: творчество группы Onmyo-Za (J-Rock)}

\author{
Э.А. Данилова ${ }^{a}$ Н.А. Еловская ${ }^{\sigma}$ \\ ${ }^{a}$ Сибирский федеральный университет \\ Россия, 660041, Красноярск, пр. Свободныий, 79 \\ ${ }^{\sigma}$ Красноярский государственный институт искусств \\ Россия, 660049, Красноярск, ул. Ленина, 22
}

Статья посвящена рассмотрению претворения особенностей американо-европейской роккультуры в ключе музыкальной, литературной и общекультурной традиций Японии. Основной целью становится выявление черт японского национального искусства, пронизывающих творчество японской рок-группь Оптуо-Zа. Основополагающими методами исследования явились метод историко-теоретического музыкознания, а также лингвистический и содержательный анализ. В статье на материале самостоятельных музыкальных композиций и композищий, входящих в состав альбомов, рассмотрены конкретные примеры культурного преломления, возникшего в связи с типичными чертами японского менталитета: заимствованием и видоизменением зарубежных черт в соответствии со своими традициями и философией. Группа Оптуо-Zа является подтверждением взятого за основу данной работьл принципа синтеза традиционного и американо-европейского начал. Композиции отличаются органичностью сплава японской национальной культуры и западной рок-музыки. Традиционно японское проявилось как на содержательном, образно-смысловом уровне, так и в музыкальном плане. Исследование показало, что стиль группь Оптуо-Za - это пример рок-музыки с органичным воплощением отличительных особенностей японских традиций, вписанной в мировой контекст рок-культуры.

Ключевые слова: J-Rock, японский, Хэйан, традиционная музыка, поэзия, японская поэзия, рок, образы, музыкальные инструменты, гагаку.

Научная специальность: 24.00.00 - культурология, 17.00.00-искусствоведение. 